\title{
Paying for Care Costs in Later Life Using the Value in People's Homes*
}

\author{
Les Mayhew ${ }^{\mathrm{a}}$, David Smith ${ }^{\mathrm{a}}$ and Duncan O’Leary ${ }^{\mathrm{b}}$ \\ ${ }^{a}$ Faculty of Actuarial Science and Insurance, Cass Business School, 106 Bunhill Row, London EC1Y 8TZ, U.K. \\ E-mail: lesmayhew@googlemail.com \\ ${ }^{\mathrm{b}}$ DEMOS Unit 1, Lloyds Wharf, 2-3 Mill Street, London SE1 2BD, U.K. \\ E-mail: duncan.oleary@demos.co.uk
}

With the number of U.K. citizens aged 75+ doubling to 10 million by 2040, and with 1.3 million people already receiving social care services in England alone, social care funding is a key public policy challenge. The government has launched a set of reforms designed to get social care funding onto a sustainable footing by establishing a new level for what individuals and the state will pay. The reforms are designed to encourage individuals to explore how best to use their available wealth and assets to meet care costs through a mixed system of local authority and private sector care-funding options. One option is to use the value in the home to bridge the cost between out-of-pocket costs and care home fees. In this article, we consider two new financial arrangements designed to meet the needs of people in different financial circumstances based on releasing equity from the home. These are an equity-backed insurance product and an "equity bank" that lets a person draw down an income from their home.

The Geneva Papers (2017) 42, 129-151. doi:10.1057/gpp.2015.34

Keywords: long-term care equity release; insurance; income drawdown

Article submitted 10 February 2015; accepted 24 November 2015; advance online publication, 9 March 2016

The online version of this article is available Open Access

\section{Introduction}

Owing to increasing longevity, the number of U.K. citizens aged $75+$ will double to 10 million by 2040 with the result that the demand for social care will increase significantly. ${ }^{1}$ If extra longevity is spent more in bad health than in good, then the consumption of social care per person will also increase. ${ }^{2}$ Unlike health care, an individual is expected to pay for his or her own social care in the U.K., although some support is available to those least able to pay. If long-term care is required in a nursing home, a typical pension income would not cover the fees, in which case, some will be forced to sell their homes or defer payment until after death.

\footnotetext{
* This paper draws on two previous research publications: Mayhew and O'Leary (2014) and Mayhew and Smith (2014a).

${ }^{1}$ Karlsson et al. (2006a, b); Forder (2007); Karlsson et al. (2007); Wittenberg et al. (2008a, b); Mayhew et al. (2010); Appleby (2013).

${ }^{2}$ For discussions of this point, see Mayhew et al. (2010) and Jagger et al. (2007).
} 
130

The problem of how to pay for care is not confined to the U.K., but is a major policy issue throughout the developed world. ${ }^{3}$ The level of support individuals can expect from the state vs the amount individuals should contribute themselves has therefore become a key issue in a debate spanning many years. ${ }^{4}$ In the U.K., some important decisions have already been taken, including the passing of the Care Act in 2014, which placed new duties on municipalities (i.e. local authorities) including an assessment of an adult's need for care and support.

Following on the recommendations of the Dilnot Commission, a key element of the legislation is to put a cap or limit on out-of-pocket care costs. ${ }^{5}$ After due consideration, the government decided to set the cap at $£ 72,000$ (equivalent roughly to 2-3 years in a care home), after which the state would pay. The cap only applies to the care element of care bills and not to accommodation costs, which individuals will continue to pay for out of pocket. This means that many could face bills estimated at well over £140k before they reach the cap, ${ }^{6}$ which is way beyond the reach of most people. Administration of the cap itself is complex, which is why the date of introduction of the cap has recently been put back from 2016 to $2020 .^{7}$

Although not everybody will need to pay for care in their lifetime and therefore have bills of this magnitude, it remains a significant risk for individuals and their families. It is estimated, for example, that around 30 per cent will need long-term care at some point in their lives and, of these, 16 per cent will reach the cap. ${ }^{8}$ We also know that a typical pension income will not be sufficient to pay care home fees without state support so that most people will struggle to find just a fraction of the costs, even if they draw down all their savings. The problem is that people are reluctant to set money aside for care, some falsely believing that their care as well as medical needs will be met free of charge by the National Health Service (NHS); even if they did save, it is unlikely that they would accrue the sums required.

Most older people in the U.K. own their own homes, and so, using their value to help pay for care is one potential solution if it is planned correctly. ${ }^{9,10}$ The most common way of releasing equity is through downsizing to a smaller home (usually at around retirement age) with the money released being used to fund lifestyle changes and to enhance retirement income. The costs of doing so can be expensive because of $\operatorname{tax}^{11}$ and moving costs, and therefore, it is not always a profitable or practical option (e.g. if the original home is of low value). One option, for example, is to downsize into bespoke retirement villages that provide

${ }^{3}$ For example, see Comas-Herrera et al. (2006); Karlsson et al. (2007); Pickard et al. (2007); Costa-Font et al. (2008); Colombo et al. (2011).

${ }^{4}$ Royal Commission on Long Term Care (1999); Wanless et al. (2006); Colombo et al. (2011); Kings Fund (2014).

5 Commission on Funding of Care and Support (2011).

${ }^{6}$ Institute and Faculty of Actuaries (2015).

${ }^{7}$ Originally the cap was to be introduced from April 2016, but its introduction is now being deferred until 2020 following an announcement by the minister responsible on 17 July 2015, www.gov.uk/government/uploads/ system/uploads/attachment_data/file/446309/Cap_on_care_acc.pdf

${ }^{8}$ Department of Health $(2013 \mathrm{a}, \mathrm{b})$.

${ }^{9}$ Mayhew et al. (2010); Just Retirement (2012); Mayhew and Smith (2014b).

${ }^{10}$ House of Lords (2013).

${ }^{11}$ Stamp Duty Land Tax is payable on the purchase of a property valued at over $£ 125 \mathrm{k}$. The amounts are 2 per cent on the portion of the purchase price up to $£ 250 \mathrm{k}$, and 5 per cent on the portion up to $£ 675 \mathrm{k}$. Rates increase to 12 per cent on the most expensive properties 
facilities, including care services, that may be needed at a later stage of life, but such options tend to be available only for the better-off.

The other way to release equity and also to remain in the home is known as equity release. Under this arrangement, a regular income or a loan is backed by the property as security and is repayable on death or sale of the home. The cost of a loan depends on interest rates, the age at which a policy is purchased and on longevity (i.e. loan duration); however, not all the equity has to be taken in one go, and there is flexibility as to how loans are repaid, which can significantly reduce lifetime costs if coupled with good financial planning and advice. If the debts accrue such that they are worth more than the home when it is sold, the industry body for equity release operates a policy of "no negative equity" so that there are no debts to the estate in these cases.

There are essentially two types of equity release: lifetime mortgages and home reversion plans. Lifetime mortgages involve taking out a type of mortgage that may be paid as income or in lump sums in which interest is compounded over time. ${ }^{12}$ The customer retains ownership of the house, and the loan is repaid when they die or move into long-term care. With home reversion, providers purchase all or part of a customer's home, either through a lump sum payment or through regular payments. Customers remain in the home, rent-free, with a lifetime lease on any unowned portion of the equity. At the end of the plan, the property is sold, and the sale proceeds are shared according to ownership proportions. ${ }^{13}$

The equity-release industry has moved on from the time in the 1980s when negative perceptions about equity release were commonplace. ${ }^{14}$ However, it is fair to say that the market is nowhere near as big as it could be with only around 20,000 new policies sold a year, although this is changing with an upsurge in demand since 2013 and new entrants into the market. The vast majority are for lifetime mortgages in which most use the funds to pay off debts, increase incomes or improve lifestyles. Hardly any loans are used to pay for care. Consumer research today cites many reasons for relatively low take-up including the complexity of the policy, the lifetime costs and the need for sound financial advice before embarking on this course. ${ }^{15}$ To put a scale on the potential for equity release, the estimated value of U.K. residential property owned by the population aged $65+$ is estimated to be worth around $£ 1.4$ th or $£ 122,000$ per person on average (source: ELSA). ${ }^{16}$ In this article we argue the case for opening up the market by using equity release in new ways to meet care costs or provide a relatively cheap form of income support in old age that do not involve the forced sale of the home.

The next section illustrates how house prices have changed relative to the cost of living, which supports our case for new products. The subsequent section, which forms the core of the article, discusses two new types of product: one is an equity-for-insurance product in which the premium is paid after death rather than from current income on the sale of the home; the second is a cheap form of equity release designed to produce a regular income

\footnotetext{
12 See Equity Release Council (2014a).

13 See Equity Release Council (2014b).

14 Terry and Gibson (2012).

15 The Future of the U.K. Equity Release Market: Consumer Insights and Stakeholder Perspectives, L. Overton and L. Fox O'Mahoney, www.repository.essex.ac.uk/14012/, accessed 25 February 2016.

${ }^{16}$ English Longitudinal Study of Ageing (ELSA), www.ifs.org.uk/ELSA, accessed 12 February 2014.
} 


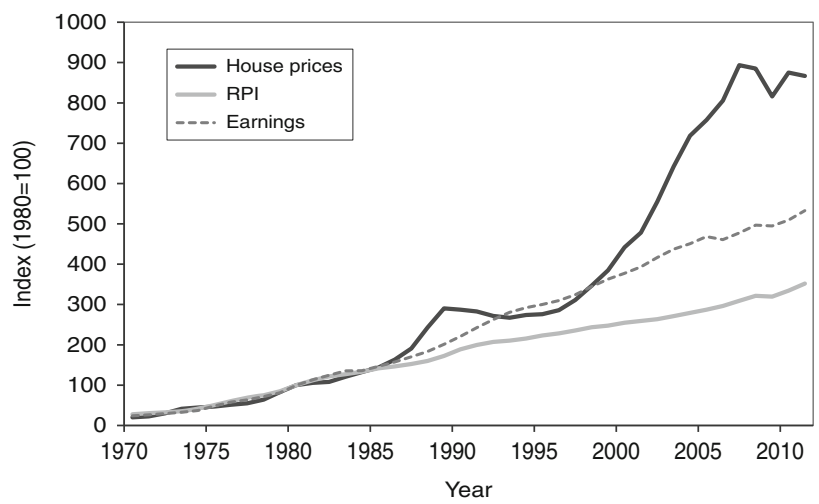

Figure 1. The change in earnings, house prices and retail prices since $1970(1980=100)$.

and to pay for care while living in their own home, which is guaranteed by the state. The penultimate section discusses the wider knock-on effects of our ideas on the tax and welfare system in the U.K., and the final section concludes. The article is supported by two technical annexes setting out how such products work from an actuarial standpoint.

\section{House prices vs cost of living}

The argument for equity release is usually justified on the basis of the upward increase in house prices over the past 25 years. Although house prices are affected by local variations in supply and demand, most homeowners reaching retirement who purchased their homes before 2000 will have accumulated substantial windfalls. As Figure 1 shows, house price inflation has outstripped the Retail Prices Index (RPI) since 1985, such that those financially benefiting the most are those that purchased before this time. If the home purchaser was aged 25 to 40 at the time, they would be between 60 and 75 years by 2020, by which time most will have paid off their mortgages.

The same graph also shows that house prices have consistently outstripped earnings after 1998, making house purchase much more problematic, especially for younger buyers. The significance of this point is that it would seem grossly unfair to ask younger generations to pay extra taxes just so the state can pay for social care for people with much greater wealth. On paper at least, older people who bought their homes when prices were lower relative to earnings are considered "rich", but are sitting on what is effectively "dormant" capital that cannot be spent, although it might be possible for them to derive a rental income.

In many cases people will be income "poor" because their pension is small or their partner is deceased and they have no other income to draw on. Releasing some of this housing capital to boost income or pay for care needs arguably becomes a strategic imperative unless the state unexpectedly changes its mind about where financial responsibility lies. The need may arise to protect some of the assets against the possibility that they will run down all their assets because of the high cost of care, especially in nursing homes, where fees can be well over $£ 1,000$ a week. In a domiciliary setting, care costs tend to be more affordable unless care is needed on a $24-\mathrm{h}$ basis. For bequest or other reasons, selling some equity in the home 
Table 1 Change in average house prices vs changes in care costs and the multiple thereof

\begin{tabular}{cccc}
\hline Year & $\begin{array}{c}\text { Average house } \\
\text { price }(A)(£)\end{array}$ & $\begin{array}{c}\text { Estimated average annual } \\
\text { cost of care }(B)(£)\end{array}$ & $\begin{array}{c}\text { Multiple } \\
(A / B)(£)\end{array}$ \\
\hline 1980 & 26,885 & 7,106 & 3.8 \\
1985 & 38,657 & 10,056 & 3.8 \\
1990 & 77,151 & 13,405 & 5.8 \\
1995 & 74,201 & 15,849 & 4.7 \\
2000 & 118,847 & 18,102 & 6.6 \\
2005 & 203,736 & 20,406 & 10.0 \\
2010 & 235,251 & 23,763 & 9.9 \\
\hline
\end{tabular}

to pay for care insurance (generally known as "long-term care insurance") may therefore be one attractive option.

Table 1 shows how average house prices and estimated annual average care home costs have changed over time. Of significance is the finding that in 1980 the annual multiple of house prices vs care costs was 3.8 but, by 2010, this had risen to 10 . It cannot be said for certain that this multiple will continue to grow, although the rising population of the U.K. and acute housing shortages suggest that it will persist for the foreseeable future. On the basis of what we know now, there is hence a one-off window of opportunity for homeowners that have gained most from house prices, which in theory could last for 30 years or more for this house-buying generation.

How many could benefit from releasing equity to pay for care? If we take the cohorts aged 50+, then, as Figure 2(a) shows, less than 20 per cent would be able to afford to pay for care more than 12 months out of pocket, even if savings are included. This is because pension income is relatively low compared with care costs and because savings would be insufficient to fill the gap. Figure 2(b), in contrast, shows that, if the value of the home is included, it would notionally extend the average homeowner's ability to pay for care for more than five years.

Clearly, this has the capability of transforming the financial landscape as long as there was greater flexibility to tap into this wealth, and the products available were both suitable and affordable. This example assumes a direct relationship between care payments and equity in the home and is not necessarily the best way to use equity, especially if individuals wish to protect their assets or to live in their own home for as long as possible. It therefore seems strange that not much has already been achieved in using housing equity for this purpose, and several reasons have been put forward.

It could be argued that rational individuals would take steps to protect their assets or put money aside to pay for future care. Clearly this is easier to say with the benefit of hindsight. Most people cannot afford to do so and would rather spend their money on current consumption. People therefore wait until the point of need, that is, they are forced into care by their circumstances. "Immediate needs" annuities are designed to deal with this problem, assuming they have sufficient funds. These pay a guaranteed income covering the cost-of-care fees in exchange for a one-off lump sum payment at the point of need. The home is unprotected because it forces the house sale if savings are insufficient. 

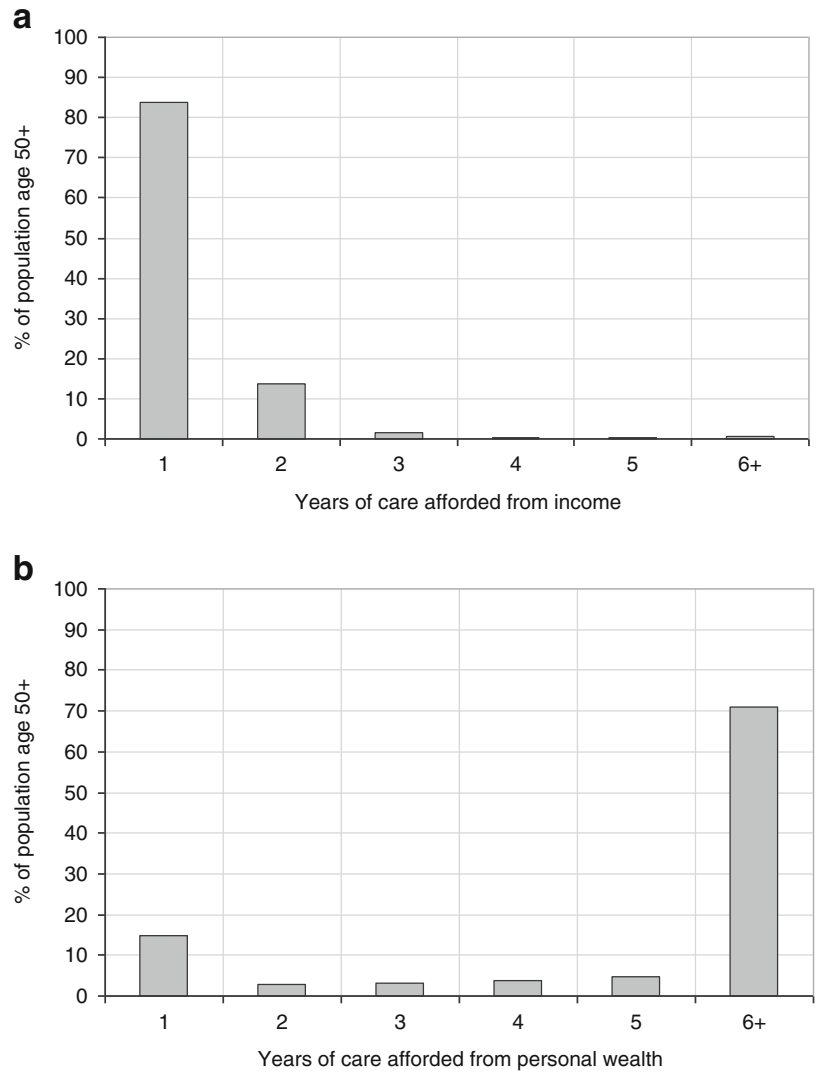

Figure 2. Years of affordable care: (a) Ability to afford long-term care costs out of income and savings; (b) Ability to afford long-term care costs if value of home is included.

Studies have identified various behavioural reasons why action is not taken sooner: ${ }^{2}$

- information gaps (not knowing the costs of care and understanding personal liability for them);

- inertia (half of all people have given no thought as to how they will pay for care, have any idea how much care costs or how the social care system works);

- incentives (people have an optimism bias and would rather spend their retirement income on pleasurable things and so risk running down their assets by not taking steps to protect them);

- moral hazard from means-testing (the belief that the state will pay some or all the costs).

One hoped-for effect of introducing the care cap is that it would enable and encourage people to plan ahead. In theory, the insurance industry would offer long-term care insurance on better terms, leading to the supply of more affordable products, although there is still little evidence of this occurring. The affordability of the premiums is a particular issue, as the cap only covers care costs and not accommodation costs; so the actual outlay for a place in a care home is much greater as was previously noted. Not only this, the market for pre-funded 
long-term care insurance has lapsed, as premiums are very expensive cutting significantly into disposable income. Even with the promise of a cap there are no signs of it reviving.

What are the consequences if nothing changes? The most obvious will be a growing funding gap in the social care system between what the state pays and the resources needed to sustain the care system. Unfortunately, it is not easy, for example, to import solutions adopted in countries such as Germany, Sweden or Japan, which face similar problems. As Karlsson et al. ${ }^{17}$ have shown, this could lead to significant tax rises, the burden of which would fall largely on younger generations, who themselves are struggling to come to terms with high housing costs. As homeownership is the main way of accumulating wealth in the U.K., the issue becomes one of making it easier to turn this wealth into cash.

\section{New financial arrangements for using equity in the home}

In this section we describe two new products built on equity-release principles. These are designed to enable people to plan ahead using housing wealth to cover care costs, whether in whole or part. In principle they go some way towards addressing the behavioural issues identified above, but we fully accept that their introduction would require a considerable amount of work, including support from both industry and government.

The products are:

- an insurance-based product in exchange for a percentage of the home with premium paid after death;

- deriving an annuity or income with debt repaid on death to help pay for daily necessities and for help around the home including basic domiciliary care costs, with the state as regulator.

The first product deals with the problem of high premiums paid for out of pension income, which individuals would rather spend on more pleasurable things. It is designed for individuals who cannot afford long-term care insurance premiums but want peace of mind.

The second product is designed to enhance income at a time when income may have declined because of the death of a partner or because their pension is insufficient to meet care needs. Its effect should enable people to live more comfortably and for longer in their own home.

Which product an individual chooses would be up to them but, basically, the insurance product would normally be considered at an earlier stage in life, say, between ages 60 and 70 , whereas the second product would not normally be needed until later in life (below we suggest age 75 and argue the reasons for this).

\section{Equity for insurance}

In greater detail, equity for insurance works by trading a percentage of housing equity for insurance cover up to the level of cover required (e.g. this could be to cover care costs up to the cap or to pay for all care fees including accommodation costs). As with all insurance products, the purchaser loses out if care is never needed, but they are fully protected otherwise.

\footnotetext{
${ }^{17}$ Karlsson et al. (2007).
} 
136

Payment of the premium is retrospective and occurs on sale of the home, either on entry into a care home or after death.

Under this proposal, the premium is linked to the difference between expected care inflation and appreciation in value of home. The mechanism would be for people to ringfence part of the equity in their homes, without having to sell or leave their home, in return for the provider covering all the individual's future care costs to the levels of cover agreed. The calculation of the premium expressed as a percentage of the equity in the home is given in technical Appendix A.

As with traditional equity-release products, the product would be "portable", allowing people to move house, subject to an updated agreement being drawn up with the provider, ring-fencing a percentage of equity in the consumer's new home. A key advantage is that consumers who were previously unwilling to make sacrifices to their current standard of living in order to insure against paying for care costs would now have a different option. Such a deal would need built-in safeguards, protecting both consumers and providers from dramatic swings in house prices. Protection would guard against the risk of house prices rising so fast that products would become hugely more expensive compared with the risk they were insuring against.

Customer guarantees could include an arrangement such that the provider could not recoup more than a fixed proportion of the care costs. There could be corresponding protection for providers against dramatic falls in house prices, that is, the product would be prevented from becoming too expensive as well as too cheap. There might be a need for limits on the age by which such a policy could be purchased to avoid the possibility of adverse selection, for example, purchasing a policy knowing that it will be triggered within a relatively short period and so on.

Other factors could influence costs of this product, especially anything likely to delay the provider from recouping the premium. For example, if an individual dies without needing care and their house is empty, the premium could be recouped fairly quickly or it could be sold on entering care. However, if there is a surviving dependant who remains in the home thus preventing its sale, the cost of the premium will be higher, although insurance agreements could be drawn up to deal with such contingencies.

Table 2 shows how much such a product would be likely to cost expressed in terms of the percentage of equity released. Columns show the predicted differences between future house price inflation and retail prices and rows the age of the purchaser. This example is based on care costs of $£ 12 \mathrm{k}$ per annum and an average length of two years of stay in a care home.

Table 2 The percentage of housing equity in payment for an equity-for-insurance product based on age and differences between house price and retail price inflation based on a home valued at $£ 200,000$ (assumes home valued at $£ 200,000$ ) (see Appendix A)

\begin{tabular}{lccccccccc}
\hline Age & $-1 \%$ & $-0.50 \%$ & $0 \%$ & $0.50 \%$ & $1.00 \%$ & $1.50 \%$ & $2.00 \%$ & $2.50 \%$ & $3 \%$ \\
\hline 50 & 4.7 & 3.9 & 3.3 & 2.8 & 2.3 & 2.0 & 1.7 & 1.4 & 1.2 \\
55 & 4.6 & 3.9 & 3.4 & 2.9 & 2.5 & 2.2 & 1.9 & 1.6 & 1.4 \\
60 & 4.4 & 3.9 & 3.4 & 3.0 & 2.7 & 2.4 & 2.1 & 1.9 & 1.7 \\
65 & 4.3 & 3.9 & 3.5 & 3.2 & 2.9 & 2.6 & 2.4 & 2.2 & 2.0 \\
70 & 4.1 & 3.8 & 3.5 & 3.2 & 3.0 & 2.8 & 2.6 & 2.4 & 2.2 \\
75 & 3.9 & 3.7 & 3.4 & 3.2 & 3.0 & 2.9 & 2.7 & 2.5 & 2.4 \\
\hline
\end{tabular}


The inclusion of accommodation costs would increase the cost two or more fold, but some of this would normally be payable from disposable pension income and so can be considered optional. Other assumptions used in this example are that it is based on an assumed current home value of $£ 200 \mathrm{k}$ and allows for a 30 per cent probability of needing care at some point in the future.

As can be seen, the results show that the wider the gap between house prices and inflation, the smaller the percentage of equity required. Highest percentages of equity are required when retail prices rise above house price inflation as might be expected, but it is also interesting that the percentages required are relatively invariant with respect to age, on the basis of this example. Just as with conventional equity-release products, should the equity released fail to cover the premium after the property is sold, the risk would be borne by the insurer and not by the estate of the individual.

\section{Deriving an income from the value of the home-the "equity bank"}

The second product is not designed to protect assets in the same way as the first. Known as the "equity bank", it is based on the idea of using the home as a low-cost method to boost income (for technical details see Appendix B). We know that there is a huge market for care services aimed at people who are not at the point where they need to go into a care home, but, because of their low income, they struggle to pay for home maintenance or basic care. Mayhew ${ }^{18}$ found that, given their greater availability, there would be wider economic benefits including a reduction in emergency admissions to hospital.

As homeowners, most would not pass the asset means-test which would qualify them for state support from their local council. Such situations arise fairly often and may be triggered by the death of a partner resulting in a sudden drop in income or coupled with rising care needs. Left unattended, their homes may fall into disrepair with domestic chores mounting up because help is unaffordable. This negative spiral continues, leading to neglect also affecting their health and well-being.

It is important that users of the equity bank have confidence in the arrangements and that charges will be proportionate and fair and the source is trustworthy. The scheme could be operated by regulated providers with the state acting as guarantor, as it does with occupational pensions. It differs from the insurance-based product in that it is designed to produce an income at an earlier stage in the care cycle, that is, before transfer to a care home.

The money homeowners require can be drawn down in small parcels, but our preferred method is based on drawing an annuity, as it is secure and unvarying until death. The product bears similarity with viager products that have been available in the continent of Europe for some time. For example, the viager intermédié partiel, a new product offered in France, enables assets to be drawn down for paying for extra needs in old age or the gifting of liquid assets to children. $^{19}$

The equity bank fulfils several aims, but like the viager product its main purpose would be to improve living standards in retirement, as well as making more money available for everyday tasks such as care services, home maintenance and respite holidays, etc. It is aimed at a sizeable group of older homeowners who have relatively small incomes of, say,

\footnotetext{
${ }^{18}$ Mayhew (2009).

${ }^{19}$ See, for example, André Masson (2012).
} 


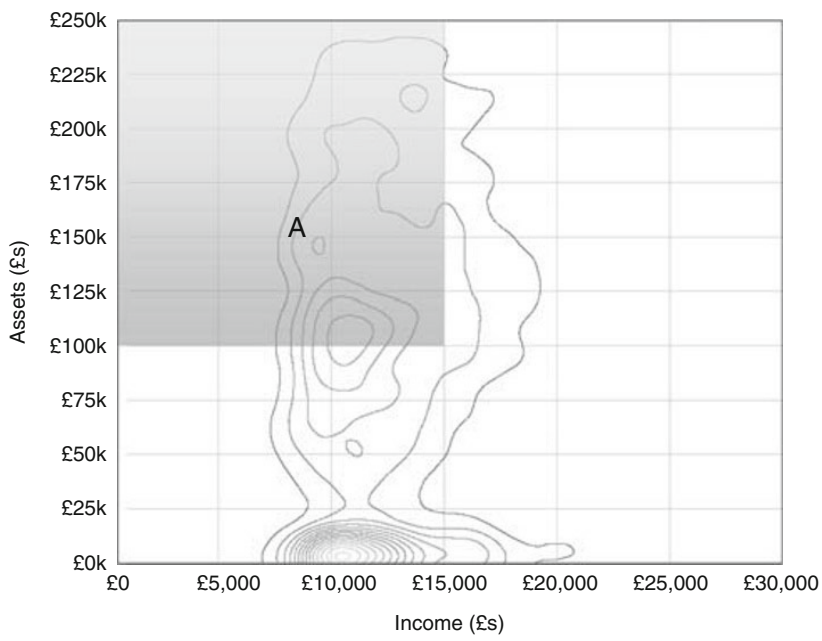

Figure 3. Contour map showing the distribution of income and wealth. The highlighted area, A, comprises an estimated 2.6 million individuals with assets of greater than $£ 100,000$ but incomes of less than $£ 15,000$.

$£ 10,000$ per annum or less, consisting mainly of the state pension and limited additional sources. A stereotypical user could be, for example, a recently widowed woman living alone aged around 75 years who is eligible for means-tested benefits such as Pension Credit or Council Tax Benefit,${ }^{20}$ in other words, not a typical purchaser of existing equity-release products.

The effect of stipulating an older start age means that lifetime costs are lower and the money is more likely to be spent on care, that is, it is more targeted. The reason why an annuity is preferred over drawdown is that the equity may run out and that borrowing costs should be lower because of scale effects (i.e. because the market would be larger). With an annuity it is also arguably easier to budget for an older person and less complicated to administer; additionally, the income would also be available and guaranteed right up to death.

The basic idea is that an individual sells a portion of their home to the state or its agent in return for a guaranteed lifetime income while remaining in their own homes. On death, the property would be sold, the debt to the state paid and any remaining value passed to the person's estate. In some respects it resembles the government's student loan scheme, which is designed to help pay for tuition fees and living costs.

Note that this differs from the government's existing universal deferred-payment system that allows eligible individuals that have moved into a care home to delay selling their homes until a later date or upon death. Meanwhile, the local authority pays the care home fees with the debt to the local authority repaid, including any interest, upon sale of the home.

We have already suggested that the target population is likely to include people who are asset rich and income poor. However, within this broad definition there are different ways of defining members of this group. A more precise definition is provided by Figure 3, which is a

${ }^{20}$ Pension Credit provides additional state-funded retirement income for people on low incomes. Council tax is a tax levied on households by local councils based on the estimated value of a property and the number of people living in it. Council Tax Benefit (now renamed the Council Tax Reduction Scheme) provides financial relief to people on low incomes. 
contour map of assets vs income in the $65+$ population (source: ELSA). ${ }^{21}$ By age 65 , most will have retired and so their income in retirement will generally be lower compared with when they were in work.

It can be seen that annual incomes tend to be concentrated in the range of $£ 7 \mathrm{k}$ to $£ 20 \mathrm{k}$, a proportion of which is made up of the state pension, which almost all pensioners receive, and any occupational pension entitlement or other sources. The distribution of asset values shows a completely different pattern, ranging from nothing to very substantial amounts. Two concentrations of contours are observed-one very dense near the $\mathrm{x}$-axis at income levels of around $£ 11,000$ and another, just above, based on similar income but more diffuse.

The feature distinguishing these groups is that the more diffuse group are homeowners and the other group concentrated near the $\mathrm{X}$-axis are not. Now consider the region of the chart covered by A; these are people with incomes of less than $£ 15,000$ but assets worth more than $£ 100,000$. We term this group as "asset rich and income poor". They comprise about 2.6 million individuals of whom 1.4 million are aged 65-74 and 1.2 million are aged 75+. Of those aged $75+$, around 400,000 are estimated to live alone. This is our target group because: (a) they have equity to release; (b) their income is low and hence (c) they stand to benefit the most; and (d) payback periods would be shorter.

\section{How the equity bank works in practice}

With any annuity product, a lump sum is paid in advance, and the policyholder receives an income until they die. In contrast, through the equity bank, the income is received first and the payment is made following the user's death. The debt value is expressed as a percentage of the home value and is recovered from the person's estate. As the income is provided upfront, we need to assume that money must be borrowed initially by the provider, which will be recouped when the house is sold.

Therefore, the cost to the user would ultimately depend on government borrowing costs, the costs of administration, and consequential changes in taxes and benefits. Theoretically, administration of the scheme could also be integrated into the welfare benefits system, where recoverable loan arrangements already exist, albeit for smaller amounts. Alternatively, it could be a role that falls to local councils as they assume new duties under the Care Act. There are possible variants in how the income amounts are calculated, but we assume that the government would want them to retain their purchasing power and so payments would be linked to price inflation (see Appendix B).

To reduce the number of variants, we use real rates of return, that is, we focus on the difference between the rates of return and price inflation and, for simplicity, assume that house price inflation is the same as price inflation. If house price inflation is assumed to be higher than the price inflation (as has historically been the case), the costs of providing the income in terms of percentage of equity will fall. Though the results are not quite identical, a real interest rate of 1 per cent could be used if price inflation is assumed to be 2 per cent and investment return is 3 per cent, or if price inflation is assumed to be 5 per cent and investment return is 6 per cent and so on.

The easiest way to demonstrate how the equity bank would work is by way of an example in which we illustrate the costs of a loan and how long it would take for the state to recoup its

\footnotetext{
${ }^{21}$ English Longitudinal Study of Ageing, www.elsa-project.ac.uk/, accessed 5 January 2016.
} 
Table 3 Capital cost in $£ 000$ s of a price inflation-linked annuity based on different start ages and borrowing rates for income levels of: (a) $£ 2,000$ p.a.; (b) $£ 3,000$ p.a.; (c) $£ 5,000$ p.a.

\begin{tabular}{lrrrrr}
\hline Age & $1 \%$ & $2 \%$ & $3 \%$ & $4 \%$ & $5 \%$ \\
\hline$(a) £ 2,000$ p.a. & & & & & \\
60 & 56.9 & 63.2 & 70.0 & 77.4 & 85.3 \\
65 & 46.4 & 50.4 & 54.6 & 59.1 & 63.7 \\
70 & 36.7 & 39.1 & 41.6 & 44.1 & 46.7 \\
75 & 28.2 & 29.5 & 30.8 & 32.1 & 33.4 \\
$(b) £ 3,000$ p.a. & & & & & \\
60 & 85.4 & 94.9 & 105.1 & 116.1 & 127.9 \\
65 & 69.6 & 75.6 & 82.0 & 88.6 & 95.6 \\
70 & 55.1 & 58.7 & 62.4 & 66.1 & 50.0 \\
75 & 42.3 & 44.2 & 46.1 & 48.1 & \\
& & & & & \\
$(c) £ 5,000$ p.a. & 142.4 & 158.1 & 175.2 & 193.6 & 213.1 \\
60 & 116.0 & 126.0 & 136.6 & 147.7 & 159.3 \\
65 & 91.9 & 97.8 & 104 & 110.2 & 83.4 \\
70 & 70.5 & 73.7 & 76.9 & 80.2 & \\
75 & & & & & \\
\hline
\end{tabular}

investment on the basis of cash flows. The model is based on ONS provisional life tables for 2010-2012 and so is representative of "average lives" who will be a mix of people in different initial states of health, some healthy and some less so. The cash-flow consequences on government expenditure are then shown for different cohorts (for simplicity 1,000 individuals are assumed) on an actuarially fair basis assuming no profit margin.

From this we are able to estimate the impact on public expenditure, including outflows and inflows, and the number of years it would take for the scheme to balance inflows and outflows. We base the following examples on females because they are more likely to be the sole survivor in cohabiting circumstances where equity is shared. Similar calculations are obviously possible for males but, because males currently live for fewer years than do females, cash flows will tend to break even sooner. Table 3 (a)-(c) illustrates the cost of providing the income (i.e. the original amount of equity that would need to be released at different ages).

Three price inflation-linked options are considered providing an initial income of $£ 2,000$, $£ 3,000$ and $£ 5,000$ a year, respectively. For example, Table 3 shows that a woman aged 75 years would need to release $£ 29,500$ worth of equity to generate an income for life of $£ 2,000$ (interest assumed at 2 per cent per annum). A younger woman aged 65, with a longer life expectancy, would need to release $£ 50,400$ at the same interest rate.

It is seen that the cost of providing the income increases significantly at higher interest rates, which is a reflection of the cost of borrowing for the equity bank to fund the scheme. For example, the $£ 5,000$ a year income in Table 3(c) where real interest rates are 5 per cent for a 65year old will cost $£ 159,300$ as compared with $£ 116,000$ at an interest rate of 1 per cent.

This may initially appear to be a counter-intuitive result, as, when the real interest rate increases, it costs more to get the same yearly income. Normally with annuities, the policyholder gets a higher income when interest rates are high, but for this policy, as the payment is made at the end of the income stream, it is more valuable the lower the discount rate and hence, less home equity needs to be ceded. 


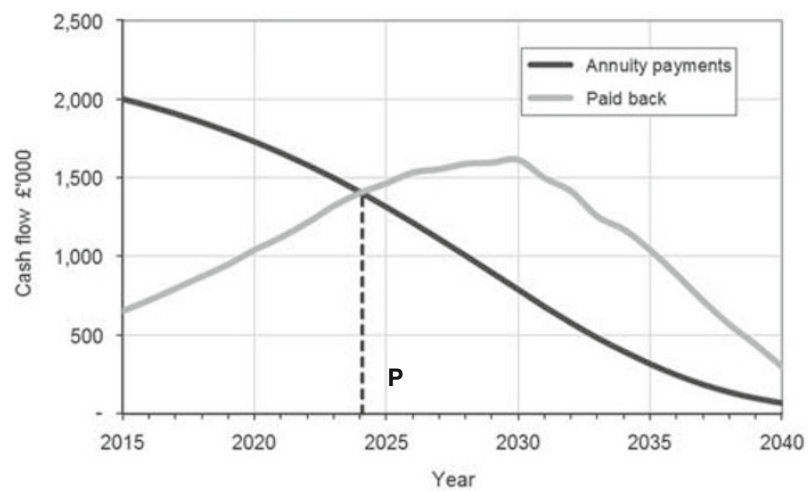

Figure 4. Chart showing cash flows for 1,000 women aged 75 in 2015 based on $£ 2,000$ annuity at 2 per cent p.a.

Table 4 Break-even year in cash flow terms by age based on providing an initial income of $£ 2,000$ p.a., and an interest rate of $2 \%$ p.a.

\begin{tabular}{ccc}
\hline Age & Loan ('000£) & Break-even year \\
\hline 60 & 63.2 & 2033 \\
65 & 50.4 & 2030 \\
70 & 39.1 & 2027 \\
75 & 29.5 & 2024 \\
\hline
\end{tabular}

In the introduction to this article, we noted that the average equity owned by an older homeowner was $£ 122 \mathrm{k}$, and in the cases where the partner was deceased, the average could therefore be twice this amount. Assuming that an individual living alone is prepared to give up half the equity in the home and that real interest rates are, say 2 per cent, then, a person releasing equity valued at $£ 122 \mathrm{k}$ would receive an annual income of $£ 3,860$ (age 60 ), $£ 4,840$ (age 65), $£ 6,250$ (age 70) and $£ 8,275$ (age 75).

From the above we can see that the up-front costs of the scheme to the state are higher at younger ages, because people live longer until the loan is recouped, and, in addition, the volumes of participants will be potentially greater. This suggests that the scheme should be introduced first at older ages before being broadened to younger ages once the scheme is established.

Figure 4 shows the predicted cash flow out of and into the equity bank on the basis of a caseload of 1,000 women aged 75 years and a start year of 2015. For an income worth initially $£ 2,000$ p.a. to each woman participating, the initial outlay is $£ 2 \mathrm{~m}$, reducing to almost zero by 2040 as the remaining survivors reach the age of 100 years. As can be seen, inflows on the sale of equity build up gradually and exceed outflow in 2024 (point P) before peaking in 2030 .

Cash flow is important, as it affects broader public expenditure choices, especially if it is introduced on a large scale with many more participants than is assumed in the example shown. Table 4 shows the break-even year (inflows equal outflows) based on the same start year as of 2015 . 
It is seen that the time is extended for younger ages because loan costs are greater and the time of death is later. Hence, there is a later switch between paying out income and recouping costs. Repayments start shortly after each person dies, and there would need to be arrangements in place to compensate people dying in the early years of taking out a plan, as there are for standard annuity products.

From a public expenditure standpoint, we conclude that the older the person the quicker the scheme will generate positive cash flows. For these reasons, we suggest an initial start age of 75 years, but this could be extended to younger ages as experience is gained and as public finances allow in the light of trends in life expectancy and the housing market.

The scheme would be rolled out in the light of actual receipts and trends in future life expectancy. Calculations based on the same assumptions as in Figure 4 and assuming 40,000 new applicants a year, each with an annual starting income of $£ 2,000$, show a buildup in expenditure to a maximum of around $£ 300 \mathrm{~m}$ per annum after nine years and falling thereafter.

To repeat, the above illustrations apply only to people living alone. In cohabiting households, extra conditions may be needed to avoid loan periods becoming overextended or the cost of loans adjusted accordingly, depending on factors such as the age difference and gender of each partner in the cohabiting case. Different calculations are needed for these cases and are not considered here.

The equity bank is likely to be more popular in some areas of the country than in others, and its local impact is obviously dependent on the number of people fitting the preferred profile. This could be an argument for schemes to be based within local authorities as previously suggested.

A case study based on six London municipalities (boroughs) in 2011 found that, of the 118,000 people aged $65+$, an estimated 75,000 were homeowners, and, of these, 36 per cent lived in households on means-tested benefits (our measure of low income). Of these, 4,900 were aged 75+ and lived in higher tax banded properties amounting to 4.1 per cent of the older population.

Given our suggestion that the scheme would initially include only people turning 75 years old each year, the numbers are correspondingly much smaller. Of the 5,800 people that turned 75 in 2011, 717 lived alone in privately owned accommodation and of these, 311 were income poor. If all 311 took out an annuity worth $£ 2,000$, the cost in the first year would only be around $£ 622,000$.

Nationally, if we restrict the market to those turning 75 each year, the potential market would be around 40,000 policies. The annual cost of the scheme would therefore depend on how many of these chose to join the scheme. The figure of 40,000 may be compared with the current market for equity release, which is currently running at around 20,000 new plans a year.

\section{Tax and welfare benefit implications}

All sums realised by any form of equity release are considered under rules for claiming welfare benefits as being capital or income. The use of our insurance-based product does not have any immediate tax or benefit consequences as far as we can tell and is not pursued further here. Suffice it to say that, by buying such a policy, an individual would not have 


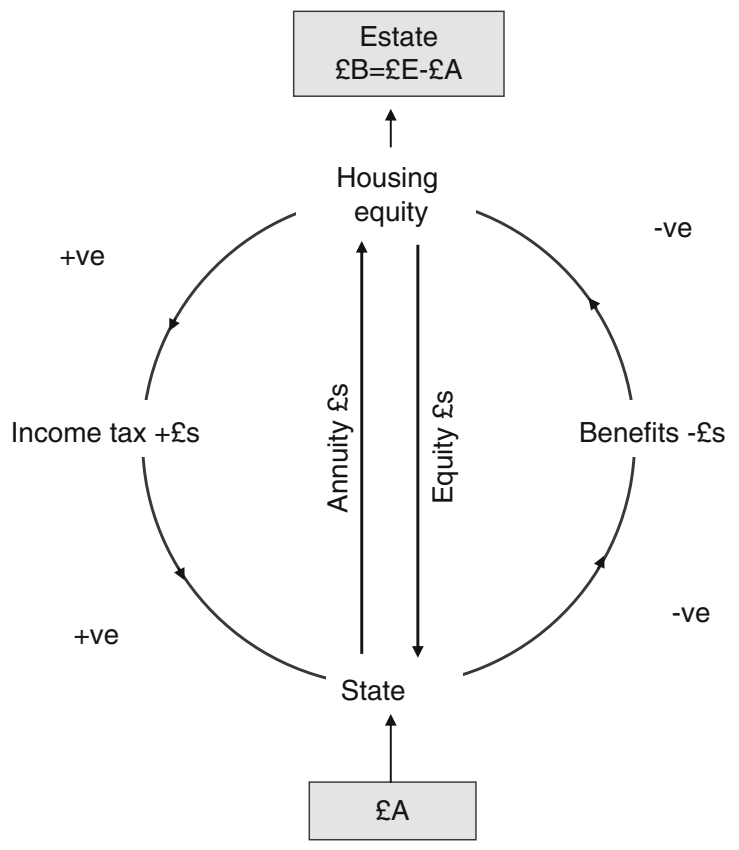

Figure 5. Chart showing money flows in the system (Key: $£ \mathrm{E}$ is value of home, $£ A$ is the equity released; $£ B$ is the residual value of the estate). Actual flows will depend on tax benefits rules.

access to means-tested financial support, because their care costs would be covered by the policy.

It is arguable that the government could provide financial incentives through the tax system to encourage people to purchase this kind of policy and several options are possible. In our case, our preferred scheme is designed to produce a regular income and so taxation rules for treatment of capital would not apply. This would be the case if a person opted, say, for an equity drawdown product, especially where the amounts drawn down put them above the capital limit for, say, pension credit purposes.

In contrast, a person using equity to generate an income may be liable to pay income tax and/or receive reduced amounts of means-tested state benefits, depending on their level of income and wealth. Currently, income tax does not apply to equity-drawdown products as long as it is from a person's main home. Clearly, the differing treatment under income tax rules could undermine the attractiveness of our proposal and therefore any social value.

The possible movements in income and tax revenues are captured in Figure 5. A fixed amount of equity is transferred to the state in exchange for a regular income. There are two accompanying flows: one is additional income tax to the Exchequer that is potentially due on any additional income; and the second is a reduction in income-related benefits flowing from the state to the individual.

For the average pensioner, the marginal rate of tax on additional income is 20 per cent for income over the personal allowance. However, income-related benefits such as pension credit and council tax benefit are also withdrawn as income increases, the pension credit at a higher withdrawal rate than the council tax benefit. A higher income 
could also result in the loss of certain health benefits such as help with dental costs or other benefits in kind.

Conversely, certain welfare benefits such as the disability living allowance, attendance allowance or winter fuel payments are not means-tested or subject to tax and so the problem appears to be limited to only a few benefits. Because our target group are over pension age, any interactions with working age benefits are thus avoided. Overall, the picture is therefore not as complicated as it might first appear and could potentially be addressed relatively simply.

Consider an average case of an older person living alone with modest savings. Two basic situations can be identified as follows:

(a) People with incomes below $£ 10,000$ do not pay income tax, but receive pension credit and help with council tax.

(b) People with taxable income over $£ 10,000$ pay income tax, do not receive pension credit and only reduced levels of help with council tax up to incomes of around $£ 14,000$.

Suppose a person decides to release equity from their home. In case (a), the financial benefit would be marginal, as most of the available extra income would be offset not by tax but by the withdrawal of pension credit and council tax benefit. In case (b), a person would be unaffected by the withdrawal of pension credit and only partly affected by council tax benefit; however, they would be affected by higher taxes due on the annuity.

Thus, a person whose income is $£ 10,000$ initially who uses her home to generate an additional income of $£ 3,000$ a year would only be around $£ 2,000$ a year better off after tax and withdrawal of council tax support. A financial advisor may conclude therefore that capital drawdown is the better option than an annuity, especially if taken in small lump sums. Such tax inconsistencies suggest that if the government wishes to proceed with the scheme, tax rules will require alteration in favour of equal tax treatment.

The most obvious option would be to disregard income from released housing equity as long as the equity is released from their main home. This would put it on a par with drawdown products, which, as noted, are also not counted as income for tax purposes. Because of the high withdrawal rate of Pension Credit it also makes sense to disregard equity-based income for the purposes of its calculation. The impact of withdrawal of Council Tax Benefit, however, is much less consequential, and there are already deductions for people living alone or are registered disabled. Clearly, further work is needed to verify and cost these suggestions.

\section{Conclusions}

This paper has sought to show that a considerable part of personal wealth in the UK is contained in housing assets, which have increased substantially in value in recent decades. Some of this group will choose to release equity through downsizing, though a majority would prefer not to have to move home because of the costs and for other reasons. We have argued that housing wealth is a decisive factor in determining how many years of care people are likely to be able to afford if they were able to release equity on the right terms.

After the most significant reforms to social care funding in living memory, there is a temptation for policymakers to believe that the mission to reform the care funding system has 
been accomplished. As the provisions in the Care and Support Bill are now law, many hope that this will create the conditions for a new market in long-term care products to flourish. However, the recently announced four-year delay to the introduction of a care cap due to the complexities of its introduction is unhelpful, as it is bound to affect the introduction of any product that requires proof of expenditure up to the cap.

This is not the case for either of the products set out in this article, as, arguably, they present opportunities both for the private sector and for the state. The inclusion of a cap on care costs is not strictly necessary for either of the financial products we have outlined, but it would make them cheaper to provide if it had the effect of lowering the premium on the equity-for-insurance product and substituted for some of the eligible care costs paid for by the equity bank. This would depend on what are counted as eligible care costs and how long it would take for them to accrue to the cap.

The equity-for-insurance policy has the important advantage that the premiums do not have to be paid out of current income, thus removing one of the key barriers to the take-up of long-term care insurance. Like all insurance products it means that if care is never needed, the premium will have been wasted. However, it is a relatively cheap way of protecting one's assets and should give people the peace of mind they seek without eating into their current standard of living. Their heirs should be happier at the prospect of not seeing their inheritance disappearing on care home fees and so should support inter-generational bonding.

The "equity bank", however, should allow users to have a more comfortable retirement and fewer financial worries and enable them to stay in their own homes for longer. Assuming that the income is inflation-protected (either linked to inflation or house prices (though this could lead to a more volatile income)), the improvement will be durable. Individuals normally trust government financial institutions more than commercial firms and so should enjoy greater peace of mind, especially if the government acts as guarantor as it does, up to a point, with bank and savings deposits and occupational pensions. There is a risk that house prices will fall once the baby boomers have died out, but we do not believe this is realistic for the simple reason that the population is projected to grow rapidly and with it, housing demand.

A consequence of both products is that individuals will pass on less to their heirs. However, unless the whole value of the home is used, users will still benefit from rising house prices. In the U.K., inheritance tax (IHT) is payable on assets once they pass a certain threshold-for individuals this is currently $£ 325 \mathrm{k}$, with 40 per cent tax due on amounts over this value. Both products should reduce liability for inheritance tax in cases where the estate is worth more than the personal threshold, so there would be a reduction in tax revenues from this source, all other things being equal. In practice, people with significant assets undertake estate planning anyway in order to reduce IHT liabilities over time by, for example, gifting money to their children or relatives (i.e. giving it with no strings attached) and through other means such as family trusts. The effect of our products on estate planning is therefore hard to anticipate but may actually be neutral.

For government policymakers, both products should help to relieve potential poverty in this vulnerable group and thereby lead to improved quality of life as well as enable people to stay in their homes for longer if they wish to. It will help make a contribution to care costs when and if they are required, and help moderate growth in state-funded social care. If house prices go up, this could be an additional source of profit for government (but only if a percentage of the home and not a fixed sum is transferred into state ownership). If a person 
146

dies early, there could be pressure on compensation to heirs (but again, not the other way around). The scheme could be designed to avoid large financial loss, but this would mean generating less income.

Whether the equity bank would have an impact on the existing equity-release industry is debatable and would depend on the details of the scheme. If equity release becomes more popular as a result of its introduction, commercial providers might receive more business from those outside the qualifying criteria as the equity release gains more market traction. The Equity Release Council agrees with us that there is a huge potential market in this area waiting to be unlocked. $^{22}$ The government may also decide to franchise the product, in which case, commercial providers could compete with, as well as against, the equity bank. They would be up against a new competitor that can borrow money cheaper, has a different pricing mechanism and has a better "brand" of trust, so sales will be harder. The extra income generated could also benefit local economies especially in towns where older people tend to congregate.

Administrative costs of either scheme have not been analysed in detail. We anticipate that these would benefit from significant economies of scale, which is an argument both for state involvement, especially in regard to the recovery of money from sale of homes after death, and for large insurers to play a major role. In fact, these tasks could be outsourced to government or private agencies. There would need to be some streamlining of information systems to ensure that estates could be settled quickly with equity creditors taking precedence over assets to be disbursed. Safeguards would be needed to ensure that policyholders did not build up other significant debts in the meantime.

On a final note, we believe it is important to come up with new ideas that deliver extra resources and wider social benefits, given the demographic and financial pressures. This article has been designed to facilitate new ways of doing this using equity release, but we should also end on a note of caution. A gap in our proposals is for those who do not own property wealth, and this needs further examination, as the incentives for this group to save are generally much lower. A related proposal for these groups is set out, for example, in Mayhew et al. ${ }^{23}$ and Mayhew and Smith; ${ }^{24}$ overall, however, the government and insurers need to apply more energy and greater imagination if these or similar ideas are to take off.

\section{References}

Appleby, J. (2013) Spending on Health and Social Care Over the Next 50 years: Why Think Long Term? London: The Kings Fund.

Colombo, F., Llena-Nozal, A., Mercier, J. and Tjadens, F. (2011) Health Wanted? Providing and Paying for LongTerm Care. OECD Health Policy Studies, Paris: OECD Publishing.

Comas-Herrera, A., Wittenberg, R., Costa-Font, J., Gori, C., Di Maio, A., Patxot, C., Pickard, L., Pozzi, A. and Rothgang, H. (2006) 'Future long-term care expenditure in Germany, Spain, Italy and the United Kingdom', Ageing \& Society 26(2): 285-302.

Costa-Font, J., Wittenberg, R., Patxot, C., Comas-Herrera, A., Gori, C., di Maio, A., Pickard, L., Pozzi, A. and Rothgang, H. (2008) 'Projecting long-term care expenditure in four European Union member states: The influence of demographic scenarios', Social Indicators Research 86(2): 303-321.

\footnotetext{
${ }^{22}$ Equity Release Council (2015).

${ }^{23}$ Mayhew et al. (2010).

${ }^{24}$ Mayhew and Smith (2014b).
} 
Commission on Funding of Care and Support (2011) Fairer Care Funding: The Report of the Commission on Funding of Care and Support, London: Her Majesty's Stationery Office, www.webarchive.nationalarchives.gov. uk/20130221130239/www.wp.dh.gov.uk/carecommission/files/2011/07/Fairer-Care-Funding-Report.pdf, accessed 12 February 2014.

Department of Health (2013a) 'Social care funding reform impact assessment', www.parliament.uk/documents/ impact-assessments/IA13-14C.pdf, accessed 5 January 2016.

Department of Health (2013b) Draft National Minimum Eligibility Threshold for Adult Care and Support: A Discussion Document, London: Her Majesty's Stationery Office, Department of Health.

Equity Release Council (2014a) 'What is equity release?', www.equityreleasecouncil.com/what-is-equity-release/, accessed 12 February 2014.

Equity Release Council (2014b) 'Statement of Principles v4', www.equityreleasecouncil.com/document-library/ statement-of-principles-v4-approved-nov-2014/, accessed 24 February 2016.

Equity Release Council (2015) Unlocking the potential: The future of equity release, http://wwwequityreleasecouncil .com/document-library/white-paper-unlocking-the-potential-the-future-of-equity/, accessed 5 January 2016.

Forder, J. (2007) Self-funded social care for older people: An analysis of eligibility, variations and future projections, PSSRU discussion paper 2505, Commission for Social Care Inspection, London.

House of Lords Select Committee on Public Service and Demographic Change (2013) Ready for Ageing? London: The Stationery Office Limited.

Institute and Faculty of Actuaries (2015) How pensions can help meet consumer needs under the new Social Care regime: An Overview, report by the Products Research Group of the Pensions and Long Term Care Working Party, www.actuaries.org.uk/research-and-resources/documents/how-pensions-can-meet-consumer-needs-undernew-social-care-regime- $a$, accessed 5 January 2016.

Jagger, C., Matthews, R., Matthews, F., Robinson, T., Robine, J.-M. and Brayne, C. the Medical Research Council Cognitive Function and Ageing Study Investigators (2007) 'The burden of diseases on disability-free life expectancy in later life', Journal of Gerontology A: Medical Sciences 62(4): 408-414.

Just Retirement (2012) The Role of Housing Equity in Retirement Planning, Reigate, U.K.: Just Retirement, www.erresearchcentre.org/wp-content/uploads/2012/07/The-role-of-housing-equity-in-retirement-planning.pdf, accessed 12 February 2014.

Kings Fund, The (2014) A new settlement for health and social care-Final report. Commission on the Future of Health and Social Care in England. London: The Kings Fund.

Karlsson, M., Mayhew, L. and Rickayzen, B. (2007) 'Long term care financing in four OECD countries: Fiscal burden and distributive effects', Health Policy 80(1): 107-134.

Karlsson, M., Mayhew, L., Plumb, R. and Rickayzen, B. (2006a) 'Future cost for long term care: Cost projections for long term care for older people in the United Kingdom', Health Policy 75(2): 187-213.

Karlsson, M., Mayhew, L. and Rickayzen, B. (2006b) Investigating the market potential for customised long term care insurance products, Actuarial Research Paper No. 174, Cass Business School, London.

Masson, A. (2012) Le viager: Une épargne pour vieux pauvres, www.tdte.fr/uploads/40_E-note\%205\%20-\%20Le\% 20viager,\%20une\%20\%C3\%A9pargne\%20pour\%20vieux\%20pauvres.pdf.

Mayhew, L., Karlsson, M. and Rickayzen, B. (2010) 'The role of private finance in paying for long term care', Economic Journal 120(548): F478-F504.

Mayhew, L. (2009) 'On the effectiveness of care co-ordination services aimed at preventing hospital admissions and emergency attendance', Health Care Management Science 12(3): 269-284.

Mayhew, L. and O'Leary, D. (2014) Unlocking the Potential. London: DEMOS, www.demos.co.uk/files/Unlocking potential_-_web.pdf?1393180449, accessed 25 February 2016.

Mayhew, L. and Smith, D. (2014a) The U.K. Equity Bank-Towards Income Security in Old Age. London: International Longevity Centre - UK (ILC-UK), www.ilcuk.org.uk/index.php/publications/publication_details/ the_uk_equity_bank_towards_income_security_in_old_age, accessed 25 February 2016 39(4): 668-692.

Mayhew, L. and Smith, D. (2014b) 'Personal care savings bonds: A new way of saving towards social care in later life', The Geneva Papers on Risk and Insurance -Issues and Practice 39(4): 668-692.

Pickard, L., Comas-Herrera, A., Costa-Font, J., Gori, C., Di Maio, A., Patxot, C., Pozzi, A., Rothgang, H. and Wittenberg, R. (2007) 'Modelling an entitlement to long-term care services for older people in Europe: projections for long-term care expenditure to 2050', Journal of European Social Policy 17(1): 33-48.

Royal Commission on Long Term Care (1999) With Respect to Old Age: Long Term Care_Rights and Responsibilities. Royal Commission on Long Term Care, Cm 4192-1, London: Her Majesty's Stationery Office.

Terry, R. and Gibson, R. (2012) Assessment of Equity Release Pilot Schemes, York, U.K.: Joseph Rowntree Foundation. 
Wanless, D., Forder, J., Fernández, J.-L., Poole, T., Beesley, L., Henwood, M. and Moscone, M. (2006) Securing Good Care for Older People-Taking A Long-Term View, London: The Kings Fund.

Wittenberg, R., Pickard, L., Malley, J., King, D., Comas-Herrera, A. and Darton, R. (2008a) Future demand for social care, 2005 to 2041: Projections of demand for social care for older people in England [online], PSSRU discussion paper 2514, PSSRU website, www.pssru.ac.uk/pdf/dp2514.pdf, accessed 5 January 2016.

Wittenberg, R., Malley, J., Comas-Herrera, A., Fernández, J.-L., King, D., Snell, T. and Pickard, L. (2008b) Future demand for social care, 2005 to 2041: Projections of demand for social care and disability benefits for younger people in England [online], PSSRU discussion paper 2512, PSSRU website, www.pssru.ac.uk/pdf/dp2512 .$p d f$, accessed 5 January 2016.

\section{Appendix A}

\section{Calculating the value of the insurance premium}

As an insurance product, we are paying a premium now that will pay for a claim in the future. Normally, with insurance, we consider the premiums to be invested in assets that generate an investment return that we can use to discount the benefits to get a present value. In this case, the premium is invested in the person's home, and the rate of return achieved is house inflation. At the same time, the costs of care are escalating and so, the net investment return is the difference between house price inflation and the cost of care, approximated here by general price inflation.

Define:

$\begin{array}{ll}x & \text { as age } \\ \text { Pinf } & \text { as annual price inflation } \\ \text { Hinf } & \text { as annual house inflation } \\ \text { Annc } & \text { as the current annual cost of care } \\ n & \text { as the number of years in care before death } \\ \text { perc } & \text { as the percentage of people who will need } \\ & \text { care } \\ l_{x} & \begin{array}{l}\text { as the number of lives aged } x \text { in a stable } \\ \text { population made up of the mortality rates of } \\ \text { the population }\end{array} \\ & \begin{array}{l}\text { as the number of lives aged } x \text { in a stable } \\ l_{x}^{s}\end{array} \\ & \begin{array}{l}\text { population in care made up of the mortality } \\ \text { rates of the population }\end{array}\end{array}$

\section{Calculation of benefits}

We assume that nobody needs care before they get to the age of 65 years.

The number of people entering care in our population aged $r$ is thus:

$$
l_{r}^{s}=\operatorname{perc} \times l_{r+n}, \text { where } r \geq 65+n .
$$

And, if we assume that our life is currently aged $x$, the cost of a year of care when they first enter is:

$$
\text { Annc } \times(1+P \text { inf })^{r-x} .
$$


Then the total cost of care at age $r$ discounted by the difference in house price and care inflation is:

$$
\text { Care }_{r}=\operatorname{Annc} \times\left(\frac{1}{1+i}\right)^{r-x} \times\left(\frac{1-(1 /(1+i))^{n}}{i}\right) \text { where } i=\frac{1+\operatorname{Hinf}}{1+\operatorname{Pinf}}-1 .
$$

The total benefit for someone currently aged $x$ is therefore:

$$
\text { Ben }=\frac{1}{l_{x}} \sum_{r=x}^{120} \text { Care }_{r} \times l_{r}^{s} \text {. }
$$

\section{Premium}

The premium is allocated at the start of the period, and hence as a nominal payment it is the same as the benefits, that is,

$$
\text { Premium }=\text { Ben } .
$$

And we then can express this as a percentage of the home equity as:

$$
\text { Equity used }=\frac{\text { Premium }}{\text { Current Value of Home }} .
$$

\section{Appendix B}

\section{Calculating the value of an annuity}

The concept of an "equity bank" can be seen as a form of an annuity. With an annuity product there is a sum paid in advance, and the policyholder receives income until they die. With our proposed product the income is received first and the payment is made following the purchaser's death. In monetary terms the amount that will be paid is unknown, although it is known in terms of house prices.

We assume that the income received is linked to price inflation.

Define:

$\begin{array}{ll}x & \text { as age } \\ \text { Pinf } & \text { as annual price inflation } \\ \text { Hinf } & \text { as annual house inflation } \\ i & \text { is interest rate required } \\ l_{x} & \begin{array}{l}\text { as the number of lives aged } x \text { in a stable } \\ \text { population made up of the mortality rates of }\end{array} \\ & \begin{array}{l}\text { the population } \\ \text { anc the amount of income received in the first }\end{array} \\ & \text { year }\end{array}$




\section{Benefit received}

Assume that income is received at the start of the year.

The first payment hence is Inc.

The second payment is $\operatorname{Inc} \times(1+\operatorname{Pinf})$ assuming that the person is still alive.

The third payment is $\operatorname{Inc} \times(1+P \operatorname{Pinf})^{2}$, etc.

The probability that someone aged $x$ at the start is alive in $t$ years is $l_{x+t} / l_{x}$

The present value of the income stream is therefore:

$$
\operatorname{Inc}\left[1+\frac{l_{x+1}}{l_{x}}\left(\frac{1+\operatorname{Pinf}}{1+i}\right)+\frac{l_{x+2}}{l_{x}}\left(\frac{1+\operatorname{Pinf}}{1+i}\right)^{2}+\frac{l_{x+3}}{l_{x}}\left(\frac{1+\operatorname{Pinf}}{1+i}\right)^{3}+\cdots\right]
$$

In standard actuarial notation this can be written as:

$$
\text { Inc } \times \ddot{a}_{x} \text { with interest rate }=\left(\frac{1+i}{1+\text { Pinf }}\right)-1 .
$$

\section{Payment}

We assume that, as the person is giving up the appreciation in their home value for the part that has been used for equity release, the later the payment is made the greater the value of the home (assuming that house price inflation is positive over the duration). Assuming that the monetary value of the home given up at the start of the contract is $X$ and that the value is taken at the end of the year of death, the value of the payment is as follows:

$$
X\left[\frac{l_{x+1}-l_{x}}{l_{x}}\left(\frac{1+H i n f}{1+i}\right)+\frac{l_{x+2}-l_{x+1}}{l_{x}}\left(\frac{1+H i n f}{1+i}\right)^{2}+\frac{l_{x+3}-l_{x+2}}{l_{x}}\left(\frac{1+H i n f}{1+i}\right)^{3}+\cdots\right]
$$

In standard actuarial notation this can be written as:

$$
X \times A_{x} \text { with interest rate }=\left(\frac{1+i}{1+H i n f}\right)-1 .
$$

\section{The cost of the arrangement}

To determine $X$, we need to calculate:

$$
X=\frac{\operatorname{Inc} \times \ddot{a}_{x}}{A_{x}}
$$

This can then be expressed as a percentage of current home value. 


\section{About the Authors}

Les Mayhew is Professor of Statistics in the Faculty of Actuarial Science and Insurance at Cass Business School, City University London. He is a former senior civil servant and a long standing associate of the International Institute for Applied Systems Analysis (IIASA) based in Laxenburg, Austria.

Duncan O'Leary is Research Director at Demos, a leading U.K. cross-party think tank. He is responsible for the management of DEMOS's research programme and, together with the Chief Executive, oversees Demos' strategic direction and fundraising. Previously he has worked in the Strategic Policy Team at the Home Office and as an advisor to a member of parliament.

David Smith is a Senior Lecturer in Actuarial Science at the Faculty of Actuarial Science and Insurance, Cass Business School, City University London. David has worked with Professor Les Mayhew in developing new methods of projecting populations as well as investigating new ways that the increasing costs of pensions and long-term care in the U.K. could be funded.

(i) This work is licensed under a Creative Commons Attribution 3.0 Unported License. The images or other third party material in this article are included in the article's Creative Commons license, unless indicated otherwise in the credit line; if the material is not included under the Creative Commons license, users will need to obtain permission from the license holder to reproduce the material. To view a copy of this license, visit http://creativecommons.org/licenses/by/3.0/ 